\title{
Apoptosis of mouse myeloma cells induced by curcumin via the Notch3-p53 signaling axis
}

\author{
YING ZHANG $^{1 *}$, XIN-YU LIN ${ }^{1,2^{*}}$, JIAO-HUI ZHANG ${ }^{1}$, ZHENG-LU XIE $^{1}$, \\ HUI DENG ${ }^{1}$, YI-FANG HUANG ${ }^{1}$ and XIAO-HONG HUANG ${ }^{1}$ \\ ${ }^{1}$ Fujian Key Laboratory of Traditional Chinese Veterinary Medicine and Animal Health; \\ ${ }^{2}$ Department of Zoology, College of Life Sciences, Fujian Agriculture and Forestry University, \\ Fuzhou, Fujian 350002, P.R. China
}

Received November 6, 2017; Accepted August 15, 2018

DOI: $10.3892 /$ ol.2018.9591

\begin{abstract}
Resistance to apoptosis is a characteristic of cancer. Curcumin has become a potential anticancer drug for its pro-apoptotic effects, but the underlying mechanisms remain unclear. Furthermore, the Notch3-p53 signaling axis serves an important role in cell fate. The present study was designed to investigate the antitumor effect of curcumin by the Notch3-p53 axis in mouse myeloma P3X63Ag8 cells. The effects of curcumin on the viability of P3X63Ag8 cells were evaluated using an MTT assay. Quantitative expression of the Notch3-p53 signaling axis-associated genes was measured by reverse transcription-quantitative polymerase chain reaction, and western blot analysis was used to investigate the expression of proteins. Additionally, flow cytometry was used to measure the ratio of apoptosis. The results demonstrated that curcumin could significantly inhibit cell viability. No significant pro-apoptotic effect was observed when the concentration of curcumin was $<30 \mu \mathrm{M}$. At $30 \mu \mathrm{M}$, curcumin-treated cells exhibited an apoptotic phenomenon, and the ratio of late apoptosis increased with the concentration of curcumin, and reached 28.4 and $51.8 \%$ in the medium- and high-dose groups, respectively. Curcumin inhibited the expression of Notch3, while the middle- and high-dose groups promoted p53. The expression of Notch3-responsive genes Hes family BHLH transcription factor 1 and Hes-related family transcription factor with YRPW motif 1 were notably promoted. Curcumin treatment significantly downregulated B-cell lymphoma-2 (Bcl-2) at the mRNA and protein levels, but upregulated Bcl-2-associated $\mathrm{X}$. These data indicated that curcumin exhibited antitumor
\end{abstract}

Correspondence to: Professor Xiao-Hong Huang, Fujian Key Laboratory of Traditional Chinese Veterinary Medicine and Animal Health, Fujian Agriculture and Forestry University, 15 Shangxiadian Road, Fuzhou, Fujian 350002, P.R. China

E-mail: xhhuang138@hotmail.com

${ }^{*}$ Contributed equally

Key words: curcumin, apoptosis, Notch3, p53, P3X63Ag8 cell effects in mouse myeloma cells with induction of apoptosis by affecting the Notch3-p53 signaling axis.

\section{Introduction}

Curcumin is the primary active component of turmeric and is part of the ginger family (Zingiberaceae). Due to it having no deleterious effects and it having a broad-spectrum anticancer activity, curcumin has become one of the most promising anticancer phytochemicals that has been frequently studied for its molecular mechanism (1-4). Accumulating evidence has indicated that curcumin may significantly inhibit the proliferation of tumor cells and induce apoptosis (5-8). Additionally, a number of studies have determined that curcumin may trigger the intrinsic apoptotic pathway $(9,10)$.

Multiple myeloma (MM) is a B-cell malignancy characterized by overabundance of monoclonal plasma cells in the bone marrow, which can cause osteolytic lesions (11). Previous studies demonstrated that direct contact between osteocytes and MM cells activates the Notch signaling pathway, increases Notch receptor expression in MM cells, particularly Notch3 and 4, and stimulates MM proliferation (12-14). The Notch signaling pathway is a highly conserved system that dictates cell fate and critically influences cell proliferation, differentiation and apoptosis (15). Notch3 is one of the four Notch receptors (Notch1-4) that are overexpressed in numerous cancer cells, including ovarian high-grade serous carcinoma (16), pancreatic cancer (17) and urothelial carcinoma (18). It has been reported that overexpression of Notch3 may be responsible for promoting tumor cell growth in human lung cancer types, including hepatocellular carcinoma and non-small cell lung cancers $(19,20)$. A similar study determined that enforced expression of Notch 3 could cause dysregulated hyperplasia of T cells (21). All these data indicated that Notch3 serves a crucial role in the anti-apoptosis of cancer cells. Components of the two families of basic helix-loop-helix transcription factors, Hes family BHLH transcription factor 1 (Hes1) and Hes-related family transcription factor with YRPW motif 1 (Heyl), are two of the main effectors of the Notch signaling pathway (22).

Tumor suppressor p53 is an important transcription factor that modulates cell death and survival (23). A previous study determined that Notch 3 regulates p53 at the post-transcriptional 
level by controlling cyclin G1 expression and the cell signal transduction circuit in hepatocellular carcinoma (24). There are a number of potential mediators of p53-induced apoptosis, including murine double minute 2 (MDM2), first apoptosis signal receptor (Fas) and leucine repeat death domain containing protein (LRDD) (25). p53 has been demonstrated to function by direct interactions with, or activation of, B-cell lymphoma-2 (Bcl-2) family proteins in the mitochondria (26). The members of the Bcl-2 family regulate apoptosis by the permeabilization of the outer mitochondrial membrane (27).

Notch3 and p53 signaling pathways are important in cell fate $(15,23)$. Curcumin is known to activate cell death signals and induce apoptosis in cancer cells by regulating multiple important cellular signaling pathways, including Notch (28); however, the effects of curcumin on Notch3 are less well studied. Therefore, the present study focused on the effect of curcumin on mouse myeloma cells and the underlying mechanisms mediated through the Notch3-p53 signaling pathway.

\section{Materials and methods}

Cell culture. Mouse myeloma P3X63Ag8 cells (Stem Cell Bank, Chinese Academy of Sciences, Shanghai, China) were cultured in Dulbecco's modified Eagle's medium (DMEM) supplemented with $10 \%$ fetal bovine serum (FBS, Hyclone; GE Healthcare Life Sciences, Logan, UT, USA) and 1\% penicillin-streptomycin (cat. no., 15140122, Gibico, Thermo Fisher Scientific, Inc., USA) and incubated in a humidified incubator containing $5 \% \mathrm{CO}_{2}$ at $37^{\circ} \mathrm{C}$. P3X63Ag8 cells were stimulated with curcumin $(0,30,40$ and $50 \mu \mathrm{M})$ for $24 \mathrm{~h}$ at $37^{\circ} \mathrm{C}$ with $5 \% \mathrm{CO}_{2}$.

MTT assay. The cells were placed into 96-well plates (Eppendorf, Hamburg, Germany) at a density of $4 \times 10^{4} / 200 \mu \mathrm{l} /$ well in DMEM (Hyclone; GE Healthcare Life Sciences) supplemented with $10 \%$ FBS and $1 \%$ penicillin-streptomycin, and cultured overnight at $37^{\circ} \mathrm{C}$. Medium was replaced with fresh DMEM containing different concentrations $(0,10,20,30,40,50,60,70$ and $80 \mu \mathrm{M})$ of curcumin (Sigma-Aldrich; Merck KGaA, Darmstadt, Germany). Following a further incubation for $24 \mathrm{~h}$ at $37^{\circ} \mathrm{C}, 20 \mu \mathrm{l}$ MTT ( $2 \mathrm{mg} / \mathrm{ml}$ ) was added to each well followed by a $4 \mathrm{~h}$ incubation at $37^{\circ} \mathrm{C}$. Viability was determined with formazan crystal pellets dissolved in dimethyl sulfoxide (Sigma-Aldrich; Merck $\mathrm{KGaA}$ ), and the absorbance of the plate was determined with a microplate reader (Bio-Rad Laboratories, Inc., Hercules, CA, USA) at $570 \mathrm{~nm}$. The results are expressed as percentage viability, calculated using the following formula:

$$
\begin{gathered}
\% \text { Viability=100 (O.D Text Item/O.D of control), } \\
\% \text { Activity=100-\%Viability. }
\end{gathered}
$$

Isolation of RNA and DNase treatment. Total RNA was extracted using TRIzol Reagent ${ }^{\circledR}$ (Sigma-Aldrich; Merck $\mathrm{KGaA}$ ). All RNA extracts were treated with DNase using a RQ1 RNase-Free DNase kit (Promega Corporation, Madison, WI, USA), according to the manufacturer's protocols.

Reverse transcription-quantitative polymerase chain reaction (RT-qPCR) assay. Synthesis of complementary DNA
(cDNA) was performed using the GoScript ${ }^{\mathrm{TM}}$ Reverse Transcription system (Promega Corporation), according to the manufacturer's protocols. Quantitative expression of the genes was conducted by qPCR using a CFX96 Touch Deep Well Real-Time PCR Detection system (Bio-Rad Laboratories, Inc.). Target genes were amplified using the primers in Table I. $\beta$-actin was employed as the endogenous control. The reaction mixture contained $6.25 \mu 12 \mathrm{X}$ GoTaq ${ }^{\circledR} \mathrm{qPCR}$ Master mix (Promega Corporation), $1 \mu \mathrm{l}$ cDNA, $0.25 \mu \mathrm{l}$ upstream and $0.25 \mu \mathrm{l}$ downstream PCR primers, and nuclease-free water up to a final volume of $12.5 \mu \mathrm{l}$. Each reaction was conducted in triplicate. The RT-qPCR reaction conditions were subjected to an initial pre-degeneration step of $95^{\circ} \mathrm{C}$ for $3 \mathrm{~min}$, followed by 39 cycles of $95^{\circ} \mathrm{C}$ for $20 \mathrm{sec}$, followed by $60^{\circ} \mathrm{C}$ for $30 \mathrm{sec}$. mRNA levels were quantified using the $2^{-\Delta \Delta \mathrm{Cq}}$ method (29) and normalized to those of $\beta$-actin. Fluorescence data were collected and analyzed with the Bio-Rad CFX Manager software 3.0 (Bio-Rad Laboratories, Inc.). The melting curves were produced following qPCR.

Western blot analysis. P3X63Ag8 cells were stimulated with curcumin $(0,30,40$ or $50 \mu \mathrm{M})$ for $24 \mathrm{~h}$ at $37^{\circ} \mathrm{C}$. Subsequently, the cells treated with indicated reagents were lysed in radioimmunoprecipitation assay buffer (Thermo Fisher Scientific, Inc., Waltham, MA, USA) with phenylmethylsulfonyl fluoride (Wuhan Boster Biological Technology, Ltd., Wuhan, China) for $30 \mathrm{~min}$ on ice. Following centrifugation at $16,000 \mathrm{x} \mathrm{g}$ for $20 \mathrm{~min}$ at $4^{\circ} \mathrm{C}$, the protein concentration was determined using a Bradford Protein Assay kit (Beijing Solarbio Science $\&$ Technology Co., Ltd., Beijing, China). Subsequently, $30 \mu \mathrm{g}$ protein was subjected to $10 \%$ SDS-PAGE electrophoresis. The separated proteins were transferred to a nitrocellulose filter membrane using the Trans-Blot ${ }^{\circledR}$ SD Semi-Dry Transfer Cell (Bio-Rad Laboratories, Inc.), according to the manufacturer's protocols. Membranes were blocked with 5\% skimmed milk powder at $4^{\circ} \mathrm{C}$ overnight and incubated with primary antibodies [anti-Notch3 rabbit polyclonal antibody (dilution, 1:1,000; cat. no., ab23426), anti-Bcl-2 associated X (Bax) rabbit monoclonal antibody (dilution, 1:8,000; cat. no., ab32503) and anti-Bcl-2 mouse monoclonal antibody (dilution, 1:500; cat. no., ab692) (all from Abcam, Cambridge, UK); anti-P53 mouse monoclonal antibody (dilution, 1:5,000; cat. no., GTX70214; GeneTex, Inc., Irvine, CA, USA); and anti- $\beta$-Actin mouse monoclonal antibody (dilution, 1:8,000; cat. no., HC201; Beijing Transgen Biotech Co., Ltd., Beijing, China)] in 5\% skimmed milk in TBS with Tween 20 (TBST) for $1 \mathrm{~h}$ at room temperature. Following three washes with TBST for 5 min each, the membrane was incubated with the appropriate secondary antibody [goat anti-mouse IgG $(\mathrm{H}+\mathrm{L})$ horseradish peroxidase (HRP)-conjugated (dilution, 1:3,000; cat. no., BA1050; Wuhan Boster Biological Technology, Ltd., Wuhan, China) and goat anti-rabbit IgG (H+L) HRP-conjugated (dilution, 1:3,000; cat. no., BA1054; Wuhan Boster Biological Technology, Ltd.) secondary antibodies] at room temperature for $1 \mathrm{~h}$, followed by washing three times with TBST for $10 \mathrm{~min}$ each time. The membrane was developed with a Western Bright enhanced chemiluminescent (ECL) kit (Advansta, Menlo Park, CA, USA).

Annexin V-fluorescein isothiocyanate (FITC)/propidium iodide (PI) apoptosis assay. Cells were harvested by 
Table I. Primers used for reverse transcription-quantitative polymerase chain reaction.

\begin{tabular}{|c|c|c|c|}
\hline Gene symbol & NCBI Ref seq no. & Sequence $\left(5^{\prime} \rightarrow 3^{\prime}\right)$ & Product length (bp) \\
\hline$\beta$-actin & NM_007393.4 & & 149 \\
\hline Forward & & TGAGAGGGAAATCGTGCGTGAC & \\
\hline Reverse & & GCTCGTTGCCAATAGTGATGACC & \\
\hline $\mathrm{p} 53$ & NM_001127233.1 & & 179 \\
\hline Forward & & ACAGGCAGACTTTTCGCCACAG & \\
\hline Reverse & & CCGTCCCAGAAGGTTCCCACT & \\
\hline Bax & NM_007527.3 & & 118 \\
\hline Forward & & TGGAGATGAACTGGACAGCA & \\
\hline Reverse & & GAAGTTGCCATCAGCAAACA & \\
\hline $\mathrm{Bcl}-2$ & NM_009741.4 & & 131 \\
\hline Forward & & CGATTGTGGCAGTCCCTTA & \\
\hline Reverse & & CCAGGATGAAGTGCTCAGGT & \\
\hline Hes1 & NM_008235.2 & & 157 \\
\hline Forward & & CAACACGACACCGGACAAAC & \\
\hline Reverse & & GGAATGCCGGGAGCTATCTT & \\
\hline Hey1 & NM_010423.2 & & 164 \\
\hline Forward & & TGCAGTTAACTCCTCCTTGCC & \\
\hline Reverse & & CGCCGAACTCAAGTTTCCATT & \\
\hline
\end{tabular}

Bcl-2, B-cell lymphoma 2; Bax, Bcl-2 associated X; Hes1, Hes family BHLH transcription factor 1; Hey1, Hes-related family transcription factor with YRPW motif 1 .

centrifugation at $1,000 \mathrm{x}$ for $5 \mathrm{~min}$, and washed twice with $500 \mu \mathrm{l}$ of PBS at room temperature. Annexin V-FITC/PI double staining kit (cat. no., KGA106; Jiangsu KeyGen Biotech Co., Ltd., Nanjing, China), according to the manufacturer's protocols, were employed to analyze apoptotic rate in cells. In brief, liquots of $1 \times 10^{6}$ cells were suspended in $500 \mu \mathrm{l}$ binding buffer followed by the addition of $5 \mu \mathrm{l}$ Annexin V-FITC and $5 \mu \mathrm{PI}$ at room temperature for $5 \mathrm{~min}$. Following incubation in the dark at $37^{\circ} \mathrm{C}$ for $5 \mathrm{~min}$, the cells were analyzed using a flow cytometer BD Accuri C6 Plus (BD Accuri ${ }^{\mathrm{TM}}$; BD Biosciences, Franklin Lakes, NJ, USA). A total of 10,000 events were measured per sample.

Statistical analysis. Differences between groups were analyzed using one-way analysis of variance and multiple comparison between the groups was performed using Tukey's post hoc test. Experimental data are expressed as the mean \pm standard error of the mean of three independent experiments. $\mathrm{P}<0.05$ was considered to indicate a statistically significant difference. Statistical analyses were performed with SPSS version 10.0 (SPSS, Inc., Chicago, IL, USA).

\section{Results}

The effect of curcumin on the proliferation of P3X63Ag8 cells. To determine the effect of curcumin on cell viability, cells were treated with different concentrations of curcumin for $24 \mathrm{~h}$, and viable cells were measured using an MTT assay. As depicted in Fig. 1, increasing concentrations of curcumin resulted in a significant decrease $(\mathrm{P}<0.01)$ in cell viability compared with the $0 \mu \mathrm{M}$ group. Notably, curcumin treatment resulted in a

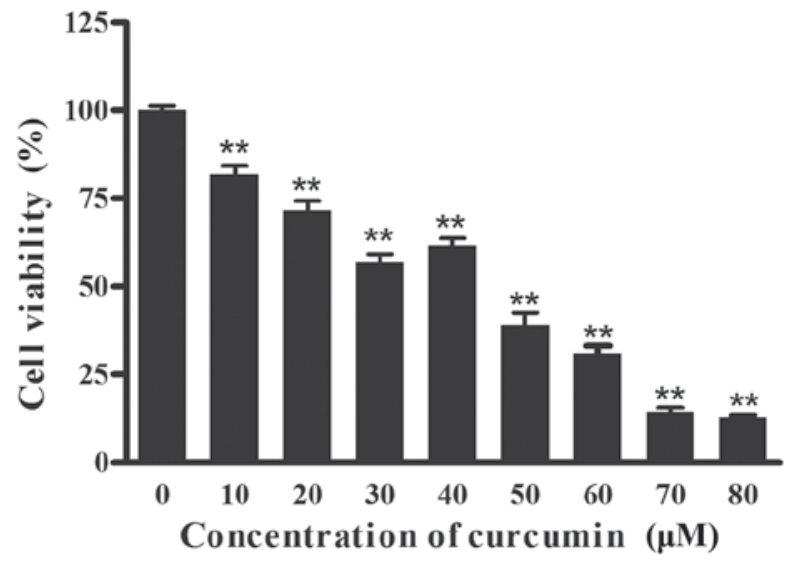

Figure 1. Effect of curcumin on the proliferation of P3X63Ag8 cells. The cells were treated with different concentrations of curcumin $(0,10,20,30,40$, $50,60,70$ and $80 \mu \mathrm{M}$ ) for $24 \mathrm{~h}$. The results are expressed as the mean \pm standard error of the mean of eight independent experiments. ${ }^{* *} \mathrm{P}<0.01$ vs. the curcumin-untreated group.

reduced inhibition at $40 \mu \mathrm{M}$, compared with $30 \mu \mathrm{M}$. A total of 3 effective concentrations $(30,40$ and $50 \mu \mathrm{M})$ were selected for all further mechanistic studies.

The effect of curcumin on the mRNA and protein levels of P3X63Ag8 cells. To determine the underlying molecular mechanisms of apoptosis of cells by curcumin, the mRNA levels of Notch3-p53 signaling axis genes were examined. Compared with the negative control group, the expression of Hes1 transcripts was significantly increased in 


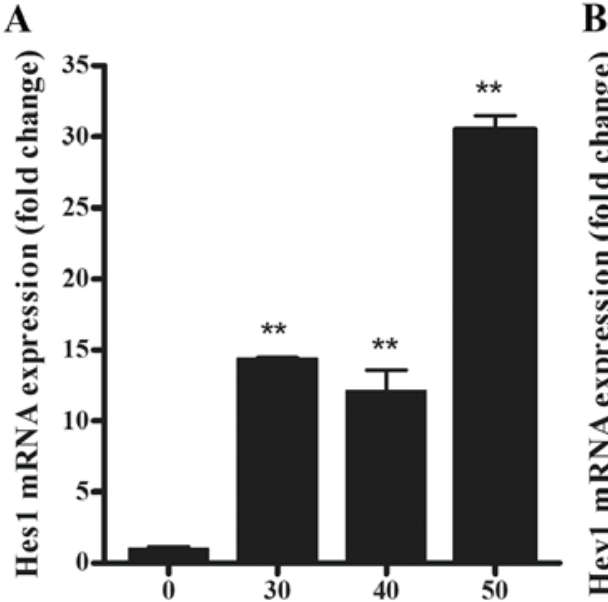

Concentration of curcumin $(\mu \mathrm{M})$

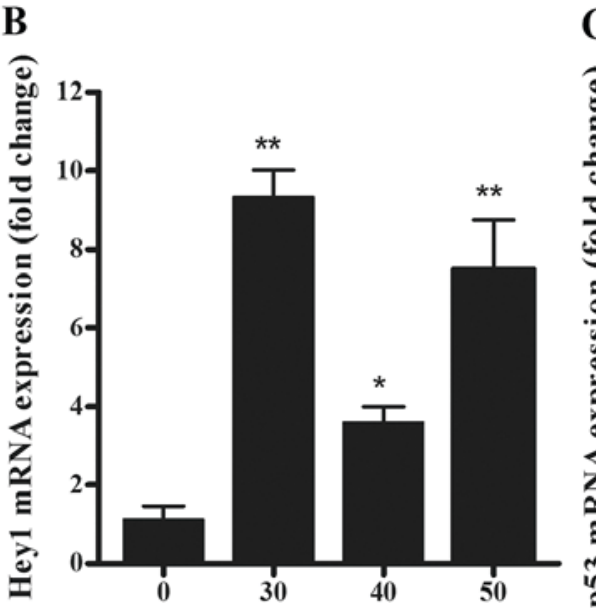

Concentration of curcumin $(\mu \mathrm{M})$
$\mathrm{C}$

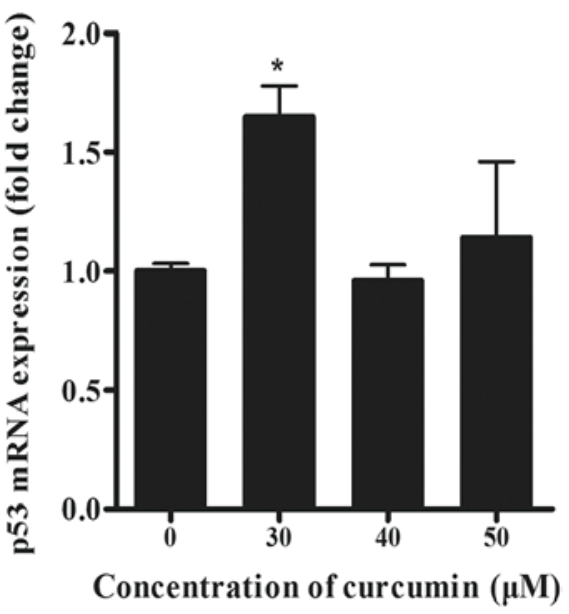

D

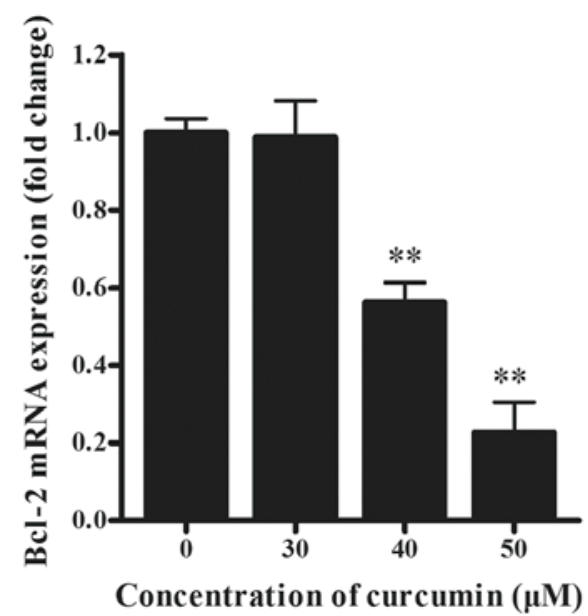

E

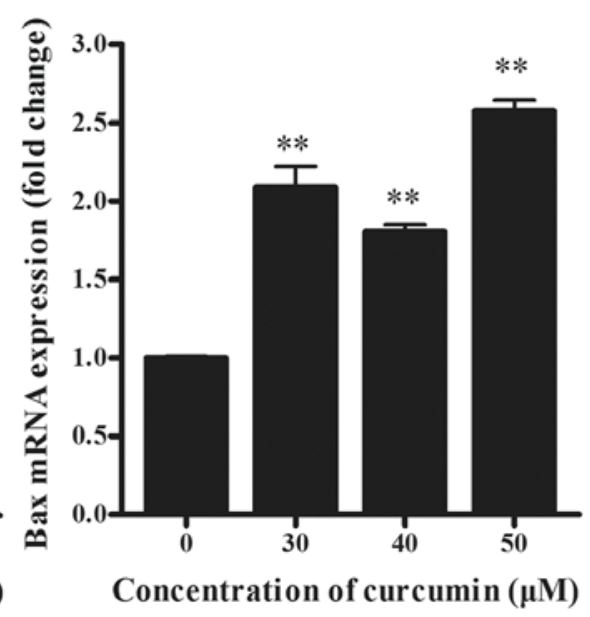

Figure 2. (A) Hes1, (B) Hey1, (C) p53, (D) Bcl-2 and (E) Bax mRNA levels of curcumin-treated $(0,30,40$ and $50 \mu \mathrm{M}$ ) P3X63Ag8 cells for $24 \mathrm{~h}$ by reverse transcription-quantitative polymerase chain reaction. The results are expressed as the mean \pm standard error of the mean of eight independent experiments. ${ }^{*} \mathrm{P}<0.05$ and ${ }^{* *} \mathrm{P}<0.01$, compared with the curcumin-untreated group. Bcl-2, B-cell lymphoma 2; Bax, Bcl-2-associated X; Hes1, Hes family BHLH transcription factor 1; Hey1, Hes-related family transcription factor with YRPW motif 1.

curcumin-treated cells (Fig. 2A; P<0.01). Similarly, the expression of Heyl mRNA copies was significantly increased in high-dose curcumin-treated cells compared with the negative control group (Fig. 2B; P<0.01). Furthermore, no significant differences were determined in the expression levels of p53 in 40 and $50 \mu \mathrm{M}$ curcumin-treated cells, compared with the control, whereas levels increased significantly in $30 \mu \mathrm{M}$ curcumin-treated cells (Fig. 2C; $\mathrm{P}<0.05$ ). As depicted in Fig. 2D, Bcl-2 mRNA was expressed at significantly reduced levels in 40 and $50 \mu \mathrm{M}$ curcumin-treated cells $(\mathrm{P}<0.01)$. By contrast, Bax transcripts were significantly overexpressed in curcumin-treated cells (Fig. 2E; P $<0.01$ ), compared with the control.

The activation status of the Notch3-p53 signaling pathways in curcumin-stimulated P3X63Ag8 cells was investigated using western blotting. The $90 \mathrm{kDa}$ band for Notch 3 was detectable in samples (Fig. 3). As predicted, Notch3 was overexpressed in P3X63Ag8 cells, compared with $\beta$-actin, and significantly decreased in curcumin-treated cells. The results demonstrated that Bcl-2 $(26 \mathrm{kDa})$ and $\mathrm{Bax}(21 \mathrm{kDa})$ protein expression levels (Fig. 3) were similar to their mRNA levels, while the p53 $(53 \mathrm{kDa})$ expression level was not similar to its mRNA levels.



Figure 3. Western blotting of Notch3, p53, Bcl-2, Bax and $\beta$-actin in P3X63Ag8 cells stimulated with $0,30,40$ and $50 \mu \mathrm{M}$ curcumin for $24 \mathrm{~h}$. Bcl-2, B-cell lymphoma 2; Bax, Bcl-2-associated X.

The effect of curcumin on the apoptosis of P3X63Ag8 cells. To examine whether curcumin could cause apoptosis, cells treated with different concentrations of curcumin $(30,40$ and $50 \mu \mathrm{M})$ were stained with PI and FITC, and analyzed by 
A
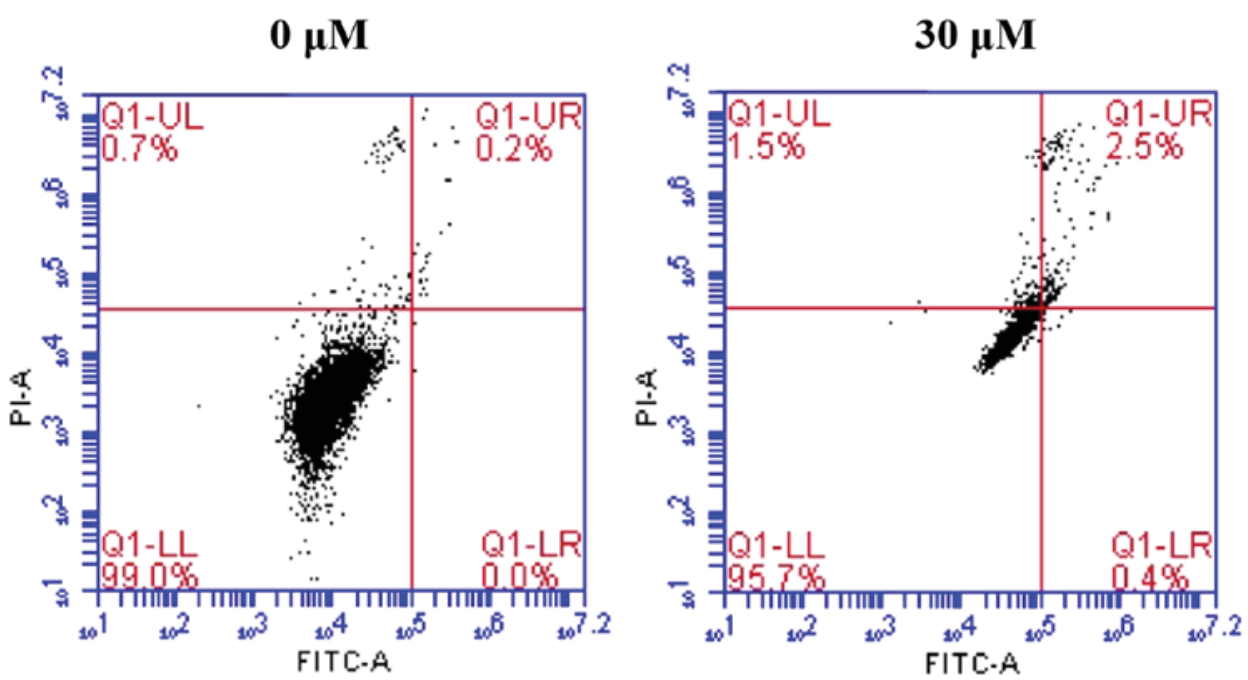

$40 \mu \mathrm{M}$

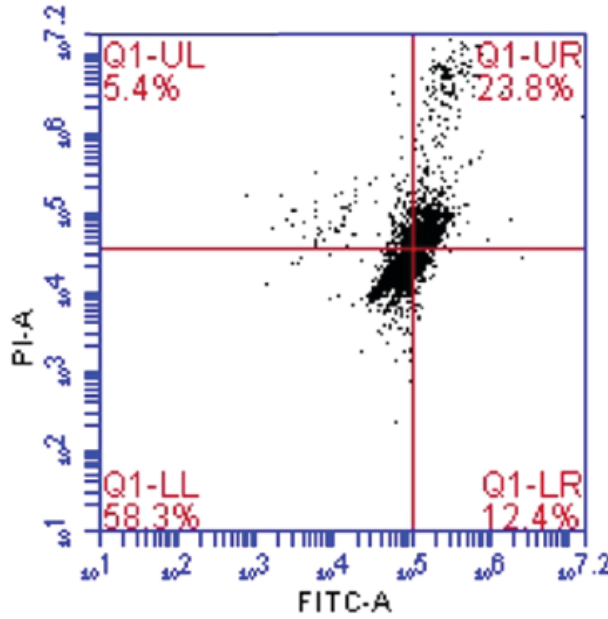

\section{$50 \mu \mathrm{M}$}

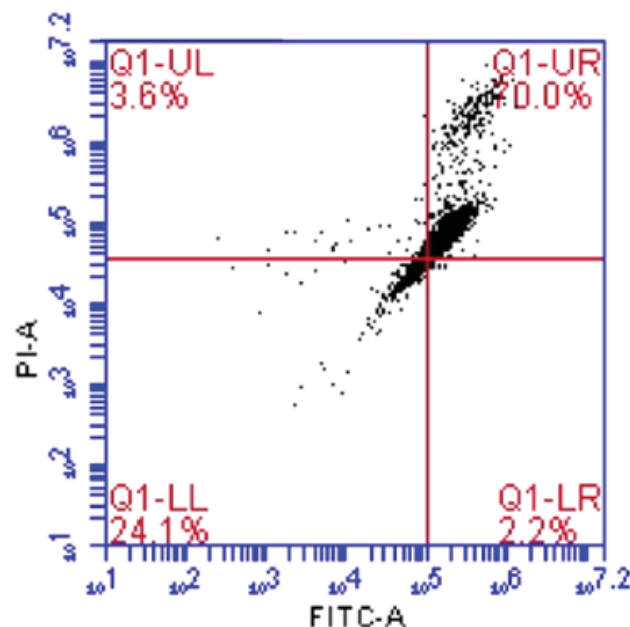

B

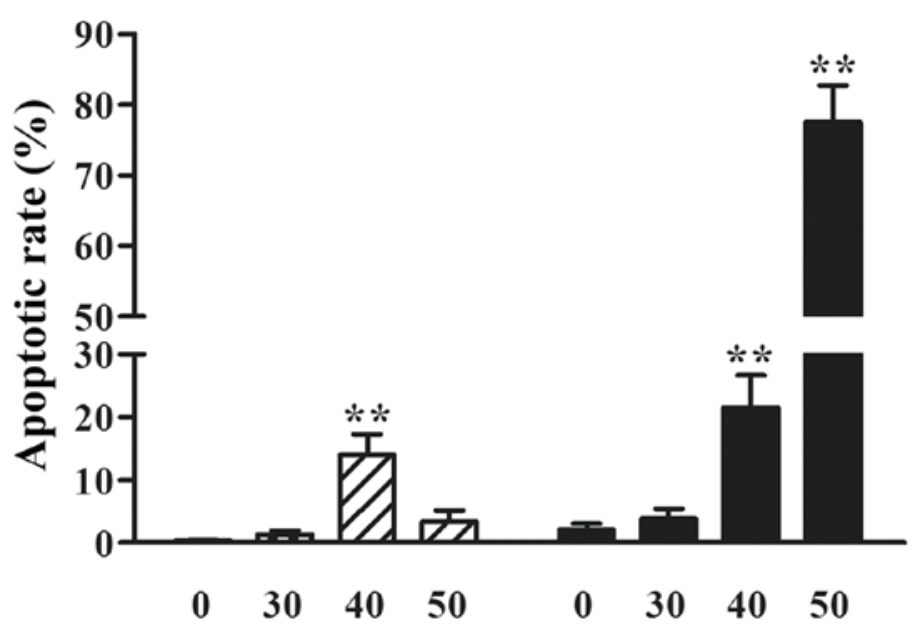

Z Early apoptosis

Late apoptosis

Concentration of curcumin $(\mu \mathrm{M})$

Figure 4. The effect of curcumin on the apoptosis of P3X63Ag8 cells. (A) Flow cytometric dot plots of one representative experiment. Results are depicted as logarithmic fluorescence intensity on the X-axis (Annexin V-FITC) vs. y-axis (PI). A total of four quadrants represent necrotic cells (Q1-UL:AV-/PI+), late apoptotic cells (Q1-UR:AV+/PI+), early apoptotic cells (Q1-LR:AV+/PI-) and viable cells (Q1-LL:AV-/PI-). The numbers indicate the percentage of cells in each quadrant and a minimum of 10,000 events were read. (B) The histogram depicts the percentage of early and late apoptosis cells \pm standard error of three independent experiments. ${ }^{* *} \mathrm{P}<0.01 \mathrm{vs}$. the curcumin-untreated group. Cells were treated with $0,30,40$ and $50 \mu \mathrm{M}$ curcumin for 24 h. FITC, fluorescein isothiocyanate PI, propidium iodide. 
fluorescence-activated cell sorting analysis. Curcumin induced apoptosis in a dose-dependent manner, with the exception in a decrease of early apoptotic rate at $50 \mu \mathrm{M}$. The percentage of late apoptosis cells was notably increased $(\mathrm{P}<0.01)$ compared with the $0 \mu \mathrm{M}$ group. As depicted in Fig. 4, the percentage of early apoptosis cells reached the highest level when stimulated with $40 \mu \mathrm{M}$ curcumin $(\mathrm{P}<0.01)$.

\section{Discussion}

Apoptosis is a multi-step, multi-pathway cell-death program that is inherent in every cell of the body. A characteristic of cancer cells is anti-apoptosis; therefore, cancer treatment is primarily dependent on inducing apoptosis (30). Curcumin has been frequently used as a spice, food additive and herbal medicine in Asia, and has not been demonstrated to cause any toxicity (31). A number of studies indicated anticancer effects for curcumin, and the mechanisms underlying these effects may be the modulation of multiple oncogenic signaling transduction elements (32-34). In the present study, it was determined that curcumin-induced mouse myeloma P3X63Ag8 cell apoptosis is mediated by modulation of the molecular targets p53, Bcl-2 and Bax. It was also demonstrated, with RT-qPCR and western blotting, that curcumin regulates the Notch3 signaling pathway. Additionally, it was observed that curcumin dose-dependently induces apoptosis in P3X63Ag8 cells, as indicated by Annexin V-FITC/PI staining.

Notch3 overexpression has been observed in a number of tumor types, including T-cell acute lymphoblastic leukemia (35), triple-negative breast cancer (36) and prostate cancer (37). Notch3 activation favors cell proliferation, resistance to apoptotic stimuli, metastatic capability and maintenance of stem cell-like features (38). The results of the present study demonstrated that the Notch3 protein was overexpressed in mouse myeloma P3X63Ag8 cells, as predicted. Furthermore, curcumin treatment significantly decreased Notch 3 protein expression, which is associated with the induction of apoptosis. p53 is a tumor suppressor and transcription factor (39). When activated, p53 induces cell cycle arrest in $\mathrm{G}_{1}$ or $\mathrm{G}_{2}$, p53 also induces cell death by apoptosis (39). The association between Notch3 and p53 has been studied in hepatocellular carcinoma $(24,40)$. The results of the present study demonstrated that curcumin significantly decreased Notch3 expression, promoting cell apoptosis, which is consistent with the anticancer effects of sorafenib and valproic acid (41). In the present study, the mRNA and protein expression level of p53 demonstrated a comparative trend, which indicated that p53 may depend on the post-transcriptional regulation of curcumin. The explanation of the post-transcriptional regulation of curcumin on $\mathrm{p} 53$ has been reported. Curcumin could upregulate scaffold/matrix attachment region 1, decreasing histone acetylation at $\mathrm{H} 3 \mathrm{~K} 9$, a lysine residue 9 on histone $\mathrm{H} 3$, and $\mathrm{H} 3 \mathrm{~K} 18$, a lysine residue 18 on histone $\mathrm{H} 3$, resulting in the inhibition of E6 promoter, which interrupts degradation of E6-mediated p53 in HPV18-infected cervical carcinoma (42). In the present study, the protein expression level of p53 is significantly increased in the middle- and high-dose groups, while the low-dose group demonstrated no significant difference. We hypothesized that the apoptosis caused by the low-dose group may not depend on p53 activation, which is different to the middle- and high-dose groups. This may be the reason for reduced inhibition at $40 \mu \mathrm{M}$, compared with $30 \mu \mathrm{M}$. From the flow cytometry results (Fig. 4), it was also speculated that the middle-dose group causes an early appearance of apoptotic cells, which is comparative to the other groups. The mechanism underlying this remains to be further investigated.

The present study indicated that Hes1 lies downstream of Notch3 and mediates Notch3 signaling-induced proliferation (43). Notably, Notch-mediated cell death has been associated with upregulation of Hes1 expression (44). Hey1, a well-known transcriptional target of Notch signaling, may be a pathway of Notch3 in sustaining mature vessel structure and vascular integrity (45). Furthermore, the expression of Hes1 and Hey1 could induce cell death through the Notch signaling pathway (15). The Bcl-2 family is able to promote or inhibit apoptosis by direct action on permeabilization of the mitochondrial outer membrane (27). Additionally, it is well known that p53 can directly regulate the expression of Bcl-2 and Bax $(26,46,47)$. To define the role of curcumin on the impact of the Notch3-p53 signaling pathway on apoptosis, the p53-responsive genes Bcl-2 and Bax were examined at the mRNA and protein expression levels (Figs. 2 and 3). Additionally, the Notch3-responsive gene Hes1 and Hey1 mRNA expression levels were measured. Curcumin inhibited the expression of Bcl-2 while promoting the expression of Bax, Hes1 and Hey1, indicating that the apoptosis effects of curcumin on P3X63Ag8 cells depend on the Notch3-p53 signaling pathway.

In conclusion, the results of the present study indicated that curcumin exhibited antitumor effects in mouse myeloma cells by inducing apoptosis through effects on the Notch3-p53 signaling pathway. Further studies are warranted to investigate the involvement of the Notch3-p53 signaling pathway in the mechanism underlying curcumin suppressing MM. Furthermore, the effect of inducing cell apoptosis by curcumin with inhibition of the Notch3-p53 signaling pathway will be the focus of our future investigations.

\section{Acknowledgements}

Not applicable.

\section{Funding}

The present study was supported by the National Natural Science Foundation of China (grant No. 31572484; Beijing, China).

\section{Availability of data and materials}

All data generated or analyzed during the present study are included in this article.

\section{Authors' contributions}

$\mathrm{XH}$ conceived and designed the experiments. Data collection and experiments were performed by YZ and XL. JZ, ZX, HD and $\mathrm{YH}$ analyzed the data. YZ, XL and YH contributed to the writing of the manuscript. All authors revised and approved the final manuscript. 


\section{Ethics approval and consent to participate}

Not applicable.

\section{Patient consent to participate}

Not applicable.

\section{Competing interests}

The authors declare no conflict of interest.

\section{References}

1. Zhang X, Wang R, Chen G, Dejean L and Chen QH: The Effects of curcumin-based compounds on proliferation and cell death in cervical cancer cells. Anticancer Res 35: 5293-5298, 2015.

2. Hu A, Huang JJ, Li RL, Lu ZY, Duan JL, Xu WH, Chen XP and Fan JP: Curcumin as therapeutics for the treatment of head and neck squamous cell carcinoma by activating SIRT1. Sci Rep 5 : $13429,2015$.

3. Balakrishna A and Kumar MH: Evaluation of synergetic anticancer activity of berberine and curcumin on different models of A549, Hep-G2, MCF-7, jurkat, and K562 cell lines. Biomed Res Int 2015: 354614, 2015.

4. Ting CY, Wang HE, Yu CC, Liu HC, Liu YC and Chiang IT: Curcumin triggers DNA damage and inhibits expression of DNA repair proteins in human lung cancer cells. Anticancer Res 35: 3867-3873, 2015

5. Mukhopadhyay A, Banerjee S, Stafford LJ, Xia C, Liu M and Aggarwal BB: Curcumin-induced suppression of cell proliferation correlates with down-regulation of cyclin D1 expression and CDK4-mediated retinoblastoma protein phosphorylation. Oncogene 21: 8852-8861, 2002.

6. Li ZC, Zhang LM, Wang HB, Ma JX and Sun JZ: Curcumin inhibits lung cancer progression and metastasis through induction of FOXO1. Tumour Biol 35: 111-116, 2014.

7. Choudhuri T, Pal S, Agwarwal ML, Das T and Sa G: Curcumin induces apoptosis in human breast cancer cells through p53-dependent Bax induction. FEBS Lett 512: 334-340, 2002.

8. Wang L, Wang L, Song R, Shen Y, Sun Y, Gu Y, Shu Y and Xu Q Targeting sarcoplasmic/endoplasmic reticulum $\mathrm{Ca}^{2}+$-ATPase 2 by curcumin induces ER stress-associated apoptosis for treating human liposarcoma. Mol Cancer Ther 10: 461-471, 2011.

9. Chang PY, Peng SF, Lee CY, Lu CC, Tsai SC, Shieh TM, Wu TS Tu MG, Chen MY and Yang JS: Curcumin-loaded nanoparticles induce apoptotic cell death through regulation of the function of MDR 1 and reactive oxygen species in cisplatin-resistant CAR human oral cancer cells. Int J Oncol 43: 1141-1150, 2013.

10. Rashmi R, Santhosh Kumar TR and Karunagaran D: Human colon cancer cells differ in their sensitivity to curcumin-induced apoptosis and heat shock protects them by inhibiting the release of apoptosis-inducing factor and caspases. FEBS Lett 538: 19-24, 2003.

11. Raab MS, Podar K, Breitkreutz I, Richardson PG and Anderson KC: Multiple myeloma. Lancet 374: 324-339, 2009.

12. Delgado-Calle J, Anderson J, Cregor MD, Hiasa M, Chirgwin JM, Carlesso N, Yoneda T, Mohammad KS, Plotkin LI, Roodman GD and Bellido T: Bidirectional notch signaling and osteocyte-derived factors in the bone marrow microenvironment promote tumor cell proliferation and bone destruction in multiple myeloma. Cancer Res 76: 1089-1100, 2016.

13. Terpos E, Ntanasis-Stathopoulos I, Gavriatopoulou M and Dimopoulos MA: Pathogenesis of bone disease in multiple myeloma: From bench to bedside. Blood Cancer J 8: 7, 2018.

14. Jundt F, Pröbsting KS, Anagnostopoulos I, Muehlinghaus G, Chatterjee M, Mathas S, Bargou RC, Manz R, Stein H and Dörken B: Jagged1-induced notch signaling drives proliferation of multiple myeloma cells. Blood 103: 3511-3515, 2004.

15. Artavanis-Tsakonas S, Rand MD and Lake RJ: Notch signaling: Cell fate control and signal integration in development. Science 284: 770-776, 1999.

16. Park JT, Chen X, Tropè CG, Davidson B, Shih IeM and Wang TL: Notch3 overexpression is related to the recurrence of ovarian cancer and confers resistance to carboplatin. Am J Pathol 177: $1087-1094,2010$
17. Dang T, Vo K, Washington $\mathrm{K}$ and Berlin J: The role of Notch3 signaling pathway in pancreatic cancer. J Clin Oncol 25: 21049-21049, 2007.

18. Zhang H, Liu L, Liu C, Pan J, Lu G, Zhou Z, Chen Z and Qian C: Notch3 overexpression enhances progression and chemoresistance of urothelial carcinoma. Oncotarget 8: 34362-34373, 2017

19. Gramantieri L, Giovannini C, Lanzi A, Chieco P, Ravaioli M, Venturi A, Grazi GL and Bolondi L: Aberrant Notch3 and Notch4 expression in human hepatocellular carcinoma. Liver Int 27: 997-1007, 2007.

20. Konishi J, Kawaguchi KS, Vo H, Haruki N, Gonzalez A, Carbone DP and Dang TP: Gamma-secretase inhibitor prevents Notch3 activation and reduces proliferation in human lung cancers. Cancer Res 67: 8051-8057, 2007.

21. Bellavia D, Campese AF, Checquolo S, Balestri A, Biondi A, Cazzaniga G, Lendahl U, Fehling HJ, Hayday AC, Frati L, et al: Combined expression of pTalpha and Notch3 in T cell leukemia identifies the requirement of preTCR for leukemogenesis. Proc Natl Acad Sci USA 99: 3788-3793, 2002.

22. Iso T, Kedes L and Hamamori Y: HES and HERP families: Multiple effectors of the Notch signaling pathway. J Cell Physiol 194: 237-255, 2003.

23. Kruiswijk F, Labuschagne CF and Vousden KH: p53 in survival, death and metabolic health: A lifeguard with a licence to kill. Nat Rev Mol Cell Biol 16: 393-405, 2015.

24. Giovannini C, Minguzzi M, Baglioni M, Fornari F, Giannone F, Ravaioli M, Cescon M, Chieco P, Bolondi L and Gramantieri L: Suppression of p53 by Notch 3 is mediated by Cyclin G1 and sustained by MDM2 and miR-221 axis in hepatocellular carcinoma. Oncotarget 5: 10607-10620, 2014.

25. Hasty P, Campisi J and Sharp ZD: Do p 53 stress responses impact organismal aging? Transl Cancer Res 5: 685-691, 2016.

26. Chipuk JE, Kuwana T, Bouchier-Hayes L, Droin NM, Newmeyer DD, Schuler M and Green DR: Direct activation of Bax by 553 mediates mitochondrial membrane permeabilization and apoptosis. Science 303: 1010-1014, 2004.

27. Czabotar PE, Lessene G, Strasser A and Adams JM: Control of apoptosis by the BCL-2 protein family: Implications for physiology and therapy. Nat Rev Mol Cell Biol 15: 49-63, 2014.

28. Subramaniam D, Ponnurangam S, Ramamoorthy P, Standing D, Battafarano RJ, Anant S and Sharma P: Curcumin induces cell death in esophageal cancer cells through modulating notch signaling. PLoS One 7: e30590, 2012.

29. Livak KJ and Schmittgen TD: Analysis of relative gene expression data using real-time quantitative PCR and the 2(-Delta Delta C(T)) method. Methods 25: 402-408, 2001.

30. Igney FH and Krammer PH: Death and anti-death: Tumour resistance to apoptosis. Nat Rev Cancer 2: 277-288, 2002.

31. Ammon HP and Wahl MA: Pharmacology of curcuma longa. Planta Med 57: 1-7, 1991.

32. Zhang L, Cheng X, Gao Y, Bao J, Guan H, Lu R, Yu H, Xu Q and Sun Y: Induction of ROS-independent DNA damage by curcumin leads to G2/M cell cycle arrest and apoptosis in human papillary thyroid carcinoma BCPAP cells. Food Funct 7: 315-325, 2016.

33. Bhullar KS, Jha A and Rupasinghe HP: Novel carbocyclic curcumin analog CUR3d modulates genes involved in multiple apoptosis pathways in human hepatocellular carcinoma cells Chem Biol Interact 242: 107-122, 2015.

34. Gali-Muhtasib H, Hmadi R, Kareh M, Tohme R and Darwiche N: Cell death mechanisms of plant-derived anticancer drugs: Beyond apoptosis. Apoptosis 20: 1531-1562, 2015.

35. Bellavia D, Campese AF, Alesse E, Vacca A, Felli MP, Balestri A, Stoppacciaro A, Tiveron C, Tatangelo L, Giovarelli M, et al: Constitutive activation of NF-kappaB and T-cell leukemia/lymphoma in Notch3 transgenic mice. EMBO J 19: 3337-3348, 2000

36. Turner N, Lambros MB, Horlings HM, Pearson A, Sharpe R, Natrajan R, Geyer FC, van Kouwenhove M, Kreike B, Mackay A, et al: Integrative molecular profiling of triple negative breast cancers identifies amplicon drivers and potential therapeutic targets. Oncogene 29: 2013-2023, 2010.

37. Pedrosa AR, Graça JL, Carvalho S, Peleteiro MC, Duarte A and Trindade A: Notch signaling dynamics in the adult healthy prostate and in prostatic tumor development. Prostate 76: 80-96, 2016.

38. Sansone P, Storci G, Giovannini C, Pandolfi S, Pianetti S, Taffurelli M, Santini D, Ceccarelli C, Chieco P and Bonafé M: p66Shc/Notch-3 interplay controls self-renewal and hypoxia survival in human stem/progenitor cells of the mammary gland expanded in vitro as mammospheres. Stem Cells 25: 807-815, 2007. 
39. Bieging KT, Mello SS and Attardi LD: Unravelling mechanisms of p53-mediated tumour suppression. Nat Rev Cancer 14: 359-370, 2014

40. Giovannini C, Gramantieri L, Chieco P, Minguzzi M, Lago F, Pianetti S, Ramazzotti E, Marcu KB and Bolondi L: Selective ablation of Notch3 in HCC enhances doxorubicin's death promoting effect by a p53 dependent mechanism. J Hepatol 50: 969-979, 2009

41. Zhu W, Liang Q, Yang X, Yu Y, Shen X and Sun G: Combination of sorafenib and Valproic acid synergistically induces cell apoptosis and inhibits hepatocellular carcinoma growth via down-regulating Notch3 and pAkt. Am J Cancer Res 7: 2503-2514, 2017.

42. Chakraborty S, Das K, Saha S, Mazumdar M, Manna A, Chakraborty S, Mukherjee S, Khan P, Adhikary A, Mohanty S, et al: Nuclear matrix protein SMAR1 represses c-Fos-mediated HPV18 E6 transcription through alteration of chromatin histone deacetylation. J Biol Chem 289: 29074-29085, 2014.

43. Song Y, Zhang Y, Jiang H, Zhu Y, Liu L, Feng W, Yang L, Wang Y and Li M: Activation of Notch3 promotes pulmonary arterial smooth muscle cells proliferation via Hes1/p27Kip1 signaling pathway. FEBS Open Biol 5: 656-660, 2015
44. Zweidler-McKay PA, He Y, Xu L, Rodriguez CG, Karnell FG, Carpenter AC, Aster JC, Allman D and Pear WS: Notch signaling is a potent inducer of growth arrest and apoptosis in a wide range of B-cell malignancies. Blood 106: 3898-3906, 2005.

45. Zaucker A, Mercurio S, Sternheim N, Talbot WS and Marlow FL: Notch3 is essential for oligodendrocyte development and vascular integrity in zebrafish. Dis Model Mech 6: 1246-1259, 2013.

46. Haldar S, Negrini M, Monne M, Sabbioni S and Croce CM: Down-regulation of bcl-2 by p53 in breast cancer cells. Cancer Res 54: 2095-2097, 1994.

47. Harn HJ, Ho LI, Liu CA, Liu GC, Lin FG, Lin JJ, Chang JY and Lee WH: Down regulation of bcl-2 by p53 in nasopharyngeal carcinoma and lack of detection of its specific t(14;18) chromosomal translocation in fixed tissues. Histopathology 28: 317-323, 1996.

This work is licensed under a Creative Commons Attribution-NonCommercial-NoDerivatives 4.0 International (CC BY-NC-ND 4.0) License. 